\title{
Statistical Analyses on Factors Affecting Retirement Savings Decision in Malaysia
}

\author{
Nurul Sima Mohamad Shariff*, Waznatul Widad Mohamad Ishak \\ Faculty of Science and Technology, Universiti Sains Islam Malaysia (USIM), Bandar Baru Nilai 71800, Nilai, Negeri Sembilan, \\ Malaysia
}

Received January 3, 2021; Revised February 1, 2021; Accepted March 12, 2021

\begin{abstract}
Cite This Paper in the following Citation Styles
(a): [1] Nurul Sima Mohamad Shariff, Waznatul Widad Mohamad Ishak, "Statistical Analyses on Factors Affecting Retirement Savings Decision in Malaysia," Mathematics and Statistics, Vol. 9, No. 3, pp. 243 - 248, 2021. DOI: 10.13189/ms.2021.090305.
\end{abstract}

(b): Nurul Sima Mohamad Shariff, Waznatul Widad Mohamad Ishak (2021). Statistical Analyses on Factors Affecting Retirement Savings Decision in Malaysia. Mathematics and Statistics, 9(3), 243 - 248. DOI: 10.13189/ms.2021.090305.

Copyright $\bigcirc 2021$ by authors, all rights reserved. Authors agree that this article remains permanently open access under the terms of the Creative Commons Attribution License 4.0 International License

\begin{abstract}
Retirement savings decision is related to the individual judgment on savings planning, and preparation for the retirement. Several factors may affect this decision towards retirement savings. Some of them are demographic factors and other determinants, such as financial knowledge and management, future expectation, social influences and risk tolerance. Due to this interest, this study aims to impact of such factors on retirement savings decision. Furthermore, this study will also discuss the retirement savings decision among Malaysians at different age groups. The data were collected through a survey strategy by using a set of questionnaires. The questions were divided into several sections on the demographic profile, Likert-scale questions on the factors, and the retirement savings decisions. The technique sampling used in this study is a random sampling with 385 respondents. As such, several statistical procedures will be utilized such as the reliability test, Kruskal-Wallis $\mathrm{H}$ test, and the ordered probit model. The results of this study found that age, financial knowledge and management, future expectation, and social influences were the significant determinants towards retirement savings decision in Malaysia.
\end{abstract}

Keywords Retirement, Savings Decision, Ordered Probit Model

\section{Introduction}

The retirement life is still unforeseen among the majority of Malaysians due to lack of awareness about the importance of at least having adequate money to support their life after retirement. This situation might worsen if the government does not make an initial step to enhance the awareness among Malaysians. It was reported that only $10.8 \%$ of households in Malaysia could afford the loss of income, or a financial crisis. The report indicated that household savings among Malaysians were relatively low, especially for the low-income households with financial instability. The rising cost of living with lower pay would weaken the decision to save for retirement, and may not be financially ready for retirement [1]. A study by Talib and Manaf [2] which was in line with this statement, found that Malaysians were still unaware and lacked the knowledge about retirement plans. They were more interested in financial factors, such as rewards and spending their money rather than saving the money for post-retirement life. Several studies in Malaysia supported the findings by Talib and Manaf [2] [3,4].

To accumulate enough savings for retirement, a long-term decision is ultimately crucial. Such decision-making strongly depends on the multiple facets of human behavior. Several factors of socio-demographic profile might affect the retirement savings decision towards the retirement plan. Some of them were highlighted in several studies conducted by Moorthy et al. [5], Mahdzan and Tabiani [6], Mansor et al. [7], and Talib and Manaf [2]. Moorthy et al. [5] found a significant evidence on the relationship between income level and retirement savings. This indicated that people who earn more money will save more for their retirement. Based on 
the Analysis of Variance (ANOVA) result in Talib and Manaf [2], it was found that the age did not related to retirement decision among the Employees Provident Fund's (EPF) employees in the Northern Region in Malaysia. This situation might be due to lack of knowledge about retirement planning that can be seen among Malaysians especially young individuals. Another study by Mahdzan and Tabiani [6] examined other related factors, and found that the gender provided a significant impact on the retirement savings decisions. The result was not in line with Mansor et al. [7] who revealed that educational level affects the savings decisions.

Besides that, financial knowledge and literacy might influence on the retirement savings decisions. Binswanger and Carman [8] examined the importance of formal planning, and simple rule of thumb on the savings accumulation of American citizens during the retirement period. They found that sophisticated savings usually required greater literacy in finance and were relatively costly. Comparatively, a simple rule of thumb may boost retirement savings of the less skilled and less literate in financial planning. The study of Lusardi and Mitchell [9] found a prevalent relationship between financial knowledge and retirement planning. With a focus on American working adults, they evidenced the interrelation between financial knowledge and retirement planning, whereby those who displayed greater financial knowledge were more likely to plan, and succeed in their retirement planning. In the same vein, Jacob-Lawson and Hershey [10] found that financial knowledge, and financial risk tolerance played a significant role in the individuals' retirement savings practices. The higher levels of these two factors were associated with more aggressive saving profiles.

Economists have always focused on theoretical factors that influenced the incentive for retirement savings. However, less attention had been highlighted to how real people arrived at the retirement savings decision-making. Mixed findings were found by previous studies with a focus more on demographic factors, such as gender, age, financial position, health, home ownership, and others. However, for the working adults in Malaysia, it was believed that there are some gaps that can be filled. Behavioral decision-making in the retirement savings could also be influenced beyond the demographic factors, such as the level of financial knowledge, future expectation, risk tolerance, government policy, and others. For example, individuals that lack financial knowledge concerning the retirement savings procedure, and have insufficient information about future expectations, or risk tolerance towards retirement savings tend to make optimal retirement decisions [10]. Social influence may also contribute to the involvement of the individual to save more. Ibrahim et al. [3] believed that highly sociable people were likely to invest in their future savings. A study suggested that socialization is another source of extra-economic influence on the savings behavior [4]. Since Malaysia is moving towards a high-income nation, the way that people could save for retirement also would be different than the previous batches by using an alternative approach. Therefore, this study will investigate the factors that affect the decision on retirement savings among Malaysians, and examine the differences of the decision on the savings across different age groups. The factors of interest are financial knowledge and management, future expectation, social influences and risk tolerance, as well as the demographic profile such as age, educational level, and income level will also be considered.

\section{Data Collection and Methodology}

\subsection{Data Collection}

Table 1. Variable description

\begin{tabular}{|c|l|}
\hline Variable & \multicolumn{1}{c|}{ Description } \\
\hline $\begin{array}{c}\text { Fnowledge and } \\
\text { Management }\end{array}$ & $\begin{array}{l}\text { An individual's knowledge, and management } \\
\text { about personal finance consequently leads to } \\
\text { personal financial management behavior [1]] }\end{array}$ \\
\hline $\begin{array}{c}\text { Future } \\
\text { Expectation }\end{array}$ & $\begin{array}{l}\text { Belief in the circumstances of life after } \\
\text { retirement based on accumulated savings that } \\
\text { may or may be unrealistic. }\end{array}$ \\
\hline Social Influence & $\begin{array}{l}\text { An influence by a group in a social situation } \\
\text { (which could be the parents, family, friends, or } \\
\text { environment) that has an influence on an } \\
\text { individual's decision on the retirement savings } \\
{[12] .}\end{array}$ \\
\hline Risk Tolerance & $\begin{array}{l}\text { The individual's risk category in the decision } \\
\text { for retirement savings, such as risk aggressive } \\
\text { (risk takers), moderate, or conservative (risk } \\
\text { adverse). }\end{array}$ \\
\hline Retirement & $\begin{array}{l}\text { An individual's judgment on planning, and } \\
\text { preparing the savings for retirement. }\end{array}$ \\
\hline
\end{tabular}

The process of data collection involved the survey procedure in this study. The sample was assumed to represent the population of the study by choosing the respondents randomly, and finally there were 385 prospective respondents who answered the survey from 500 targeted respondents. With the successful response rate of $77 \%$, the collected sample was more than sufficient to generalize the findings to the population. The survey was structured in two sections, which included the demographic questions in the first section, while five subsections as proxies of five variables were designed in the second section. The five variables were: financial knowledge and management, future expectation, retirement savings decision, social influences on retirement savings, and the risk tolerance on other investments. The format of these variables was based on a five-point Likert scale of 1, 2, 3, 4, and 5. The number indicated the responses to the questions of "strongly disagree", "disagree", "neutral", "agree", and "strongly agree". The brief description of the variables is shown in 
Table 1 . The set of questions was developed by reviewing and assessing previous related studies before being distributed via electronic survey form.

\subsection{Methodology}

To achieve the aim of the study, a few statistical procedures were employed. Amongst them were:

i. Descriptive statistics: At the initial stage of analysis, the frequency and percentage of each category based on the socio-demographic profile are computed. This result will illustrate the behavior of the sample in terms of categories' variation for each demographic profile.

ii. Reliability test: This test is performed to measure the validity of the questions in the survey item [13]. The result of the test will provide the Croncbach's Alpha of the question, and the question is considered acceptable and valid if the Croncbach's Alpha is greater than 0.7 [14].

iii. Kruskal-Wallis $\mathrm{H}$ test: Due to the variable of interest in categorical form, this test is employed to investigate the retirement savings decision of working individuals for different age groups. The test is significant if the p-value is less than 0.05 , indicating the retirement savings decisions are different across the different age groups.

iv. Ordered probit model: The impact of the factors towards retirement savings decision was investigated by using the ordered probit model [15]. Despite employing the general regression to model the relationship, this model will provide a reliable result in treating the categorical variation of variables.

\subsection{The Ordered Probit Model}

The study employs an ordered probit model with $i$-th respondent is based on an unobserved variable $y_{i}^{*},(i=$ $1,2, \ldots, n)$. Here, $y_{i}^{*}$ is related to a $(k \times 1)$ vector of explanatory variables $x_{k, i}$ with $k=7$ (age, educational level, income level, financial knowledge and management, future expectation, social influence and risk tolerance) via the model:

$$
y_{i}^{*}=\beta_{0}+\beta_{k}{ }^{\prime} x_{k, i}+\varepsilon_{i}
$$

where constant $\beta_{0}$ is the parameter of the model, $\beta_{k}$ is a $(k \times 1)$ coefficient vector and $\varepsilon_{i}$ is assumed to be normally distributed. Model in (1) can be written as

$$
y_{i}^{*}=\mathbf{X}_{i} \boldsymbol{\beta}+\varepsilon_{i}
$$

where $\mathbf{X}_{i}=\left(1 x_{k, i}{ }^{\prime}\right)$ and $\boldsymbol{\beta}=\left(\beta_{0} \beta_{k}{ }^{\prime}\right)$, respectively.

The unobserved variable $y_{i}^{*}$ is defined for retirement saving decision under the threshold of $\mu_{j-1}<y_{i}^{*}<$ $\mu_{j}$ and $j$ is the order of the ordinal variable $(j=$ $1,2, \ldots, m)$. In this study, the observed variable, $y_{i}$ will take the following form based on five-point Likert scale of $1,2,3,4$, and 5 . As such, $m=5$ will be used as the order of the ordinal variable.

$$
\begin{aligned}
& y_{i}=1 ; \text { if } \mu_{0}<y_{i}^{*} \leq \mu_{1}, \\
& y_{i}=2 ; \text { if } \mu_{1}<y_{i}^{*} \leq \mu_{2}, \\
& y_{i}=3 ; \text { if } \mu_{2}<y_{i}^{*} \leq \mu_{3}, \\
& y_{i}=4 ; \text { if } \mu_{3}<y_{i}^{*} \leq \mu_{4}, \\
& y_{i}=5 ; \text { if } \mu_{4}<y_{i}^{*} \leq \mu_{5} .
\end{aligned}
$$

The estimation for different $y_{i}$ is determined by the threshold parameters $\mu_{j}(j=1,2, \ldots, 5)$ and $\mu_{j}$ are interpreted as intercepts in equations (3). Each ordinal outcome is computed via the following probabilities:

$$
\begin{gathered}
\mathbf{P}\left(y_{i}=\mathbf{1} \mid \mathbf{X}_{i}\right)=\Phi\left(\mu_{1}-\mathbf{X}_{i} \boldsymbol{\beta}\right)-\Phi\left(\mu_{0}-\mathbf{X}_{i} \boldsymbol{\beta}\right), \\
\mathbf{P}\left(y_{i}=\mathbf{2} \mid \mathbf{X}_{i}\right)=\Phi\left(\mu_{2}-\mathbf{X}_{i} \boldsymbol{\beta}\right)-\Phi\left(\mu_{1}-\mathbf{X}_{i} \boldsymbol{\beta}\right), \\
\mathbf{P}\left(y_{i}=\mathbf{3} \mid \mathbf{X}_{i}\right)=\Phi\left(\mu_{3}-\mathbf{X}_{i} \boldsymbol{\beta}\right)-\Phi\left(\mu_{2}-\mathbf{X}_{i} \boldsymbol{\beta}\right), \\
\mathbf{P}\left(y_{i}=\mathbf{4} \mid \mathbf{X}_{\boldsymbol{i}}\right)=\Phi\left(\mu_{4}-\mathbf{X}_{i} \boldsymbol{\beta}\right)-\Phi\left(\mu_{3}-\mathbf{X}_{i} \boldsymbol{\beta}\right) \\
\mathbf{P}\left(y_{i}=\mathbf{5} \mid \mathbf{X}_{i}\right)=1-\Phi\left(\mu_{4}-\mathbf{X}_{i} \boldsymbol{\beta}\right) .
\end{gathered}
$$

where $\Phi($.$) is the standard normal cumulative distribution$ function for the given value. The threshold values must possess the following range to ensure the positive values of probabilities in (4).

$$
\mu_{1}<\mu_{2}<\mu_{3}<\mu_{4}
$$

The marginal effect of the changes in the independent variable $\mathbf{X}_{\boldsymbol{i}}$ is obtained by taking the partial derivative of the probabilities in (4) with respect to $x_{k}$. The parameter $\mu_{j}$ and $\boldsymbol{\beta}$ are then estimated by the following log-likelihood function:

$$
L=\sum_{i=1}^{n} \sum_{j=1}^{m} \log \left[\Phi\left(\mu_{j}-\mathbf{X}_{i} \boldsymbol{\beta}\right)-\Phi\left(\mu_{j-1}-\mathbf{X}_{i} \boldsymbol{\beta}\right)\right](6)
$$

\section{Results and Discussion}

A total of 385 respondents were quantified with the demographic statistics summarized in Table 2. The majority of the respondents were from the age group of 20-29 years old $(57.9 \%)$, and $50.9 \%$ were single. As for the education level, $40.8 \%$ of the respondents were commencing a Bachelor's Degree and half of them were serving in the government sector. Despite that, $30.6 \%$ earned a monthly income on average of approximately RM1,001 - RM3,000 which might fall under the low-income individual. Based on this frequency table, it could be summarized that most of the respondents were young working adults from various educational levels. As such, this sample is said to be sufficiently applicable to represent the population of the study to meet the objective of this study. 
Table 2. Summary of respondents by demographic factors

\begin{tabular}{|c|c|c|c|}
\hline Profile & Category & Frequency & Percentage $(\%)$ \\
\hline \multirow{2}{*}{ Gender } & Male & 87 & 22.6 \\
\hline & Female & 298 & 77.4 \\
\hline \multirow{3}{*}{ Marital Status } & Married & 189 & 49.1 \\
\hline & Single & 196 & 50.9 \\
\hline & Other & 0 & 0.0 \\
\hline \multirow{5}{*}{ Age } & 20-29 years old & 223 & 57.9 \\
\hline & 30-39 years old & 92 & 23.9 \\
\hline & 40-49 years old & 26 & 6.8 \\
\hline & $50-59$ years old & 41 & 10.6 \\
\hline & 60 years old and above & 3 & 0.8 \\
\hline \multirow{5}{*}{ Educational Level } & SPM & 20 & 5.2 \\
\hline & $\begin{array}{c}\text { STPM or Matriculation or } \\
\text { Diploma }\end{array}$ & 98 & 25.5 \\
\hline & $\begin{array}{c}\text { Bachelor's degree or Professional } \\
\text { Certificate }\end{array}$ & 157 & 40.8 \\
\hline & Master or Doctorate & 96 & 24.9 \\
\hline & Others & 14 & 3.6 \\
\hline \multirow{5}{*}{ Occupation } & Government & 194 & 50.4 \\
\hline & Private & 108 & 28.1 \\
\hline & Self-employed & 20 & 5.2 \\
\hline & Unemployed & 51 & 13.2 \\
\hline & Others & 12 & 3.1 \\
\hline \multirow{5}{*}{ Income Level } & RM 1000 and below & 118 & 30.6 \\
\hline & RM 1001 - RM 3000 & 122 & 31.7 \\
\hline & RM 3001 - RM 5000 & 54 & 14.0 \\
\hline & RM 5001 - RM 10000 & 89 & 23.1 \\
\hline & Above RM10 001 & 2 & 0.5 \\
\hline
\end{tabular}

The reliability of the survey items for each factor was analyzed in the pilot study (with a sample size of 50) and presented in Table 3 . The results showed that the variables on financial knowledge and management, future expectation, social influences and retirement savings decisions were acceptable with the value of the Croncbach's Alpha greater than 0.7, and therefore applicable to be used in the next procedure, except for the variable on risk tolerance on other investments. The questions on the risk tolerance were omitted in the questionnaire and it was assumed to be unreliable for this study.

Table 3. Reliability test result

\begin{tabular}{|c|c|c|}
\hline Variables & $\begin{array}{c}\text { Number of } \\
\text { Items }\end{array}$ & $\begin{array}{c}\text { Croncbach's } \\
\text { Alpha }\end{array}$ \\
\hline $\begin{array}{c}\text { Financial knowledge and } \\
\text { management }\end{array}$ & 13 & 0.867 \\
\hline Future expectation & 10 & 0.710 \\
\hline Social influence & 12 & 0.934 \\
\hline Risk tolerance & 6 & 0.308 \\
\hline Retirement savings decision & 11 & 0.943 \\
\hline
\end{tabular}

Table 4. Summary of Kruskal-Wallis H Test

\begin{tabular}{|c|c|c|c|}
\hline Variable & Age & $\mathbf{N}$ & Mean Rank \\
\hline \multirow{6}{*}{$\begin{array}{c}\text { Retirement } \\
\text { Saving } \\
\text { Decision }\end{array}$} & $20-29$ & 223 & 206.91 \\
\hline & $30-39$ & 92 & 207.4 \\
\hline & $40-49$ & 26 & 152.92 \\
\hline & $50-59$ & 41 & 120.18 \\
\hline & $>60$ years & 3 & 60 \\
\hline & Total & 385 & \\
\hline \multicolumn{4}{|c|}{ Test Statistics } \\
\hline \multicolumn{4}{|c|}{ Retirement Savings Decision } \\
\hline \multicolumn{2}{|c|}{ Kruskal-Wallis $H$ test statistics } & \multicolumn{2}{|c|}{30.316} \\
\hline \multicolumn{2}{|c|}{$\mathrm{df}$} & \multicolumn{2}{|c|}{4} \\
\hline \multicolumn{2}{|c|}{ p-value } & \multicolumn{2}{|c|}{$0.00 * *$} \\
\hline
\end{tabular}

Note: ** shows that the test statistics is statistically significant at 0.05 level of significance.

The Kruskal-Wallis $\mathrm{H}$ Test result in Table 4 revealed that there was a significant difference of savings decisions 
across the different age groups with the p-value less than 0.05 . This result indicated those who were either in the younger or older age groups might have different ways in planning for their retirement savings. This result is in line with the findings by Shariff and Isah [4] yielding that the decision towards retirement savings varied as the age increases. The result of the ordered probit regression for the stated model in (2) is presented in Table 5. Based on the overall findings, four variables which were age, financial knowledge and management, future expectation, and social influences were statistically significant, and could be considered as the factors of retirement savings decisions. Although, the coefficient of regression could not be directly interpreted, the sign of the coefficient, either positive or negative sign, could reveal the direction of a change in the dependent variable (retirement savings decision) to the explanatory variables as in the model (2) [16].

A brief discussion of the significant explanatory variables on the retirement savings decision based on the marginal effects is described as follows:

i. Age: The probability of the response "strongly agree", and "agree" increased respectively, by $0.28 \%$ and $1.43 \%$, while the probability of the response "neutral" showed a decrease by $0.78 \%$. This result indicated that the age variable also showed a negative significant influence on the retirement savings decision. As the age increases, the probability to have a bad behavioral on retirement savings decreases, which means that the people are more inclined to have a good savings decision. ii. Financial knowledge and management and future expectation: The increase in the lack of financial knowledge and management, and future life awareness leads to the increase of the bad retirement behavior. This statement showed that the probability of the response "strongly agree" decreased by $0.88 \%$ and $0.49 \%$, respectively, and the probability of the response "agree" decreased by $4.49 \%$ and $2.54 \%$, respectively. Likewise, the probability of the response "neutral" increased by $2.47 \%$ and $1.39 \%$, respectively, the probability of the response "disagree" increased by $0.86 \%$ and $0.49 \%$, respectively, and the probability of the response "strongly disagree" increased by $0.1 \%$ and $0.06 \%$, respectively. These findings showed that the financial knowledge and management, and future expectation were important factors to quantify the effect on decision changes towards the retirement savings.

iii. Social influences: The coefficient of social influence was negative indicating that as the level of social influence increases, the probability to have a bad decision on retirement savings decreases. The response of "strongly agree" and "agree" increased respectively, by $0.41 \%$ and $2.11 \%$, the probability of the response "neutral" showed a decrease by $1.15 \%$. The main reason of this result was due to influences mainly from friends and social media with intentional and unintentional efforts that could change the beliefs, attitudes, or lifestyles of other individuals' decisions towards the retirement savings.

Table 5. The Ordered Probit Regression and the Mean Marginal Effect

\begin{tabular}{|c|c|c|c|c|c|c|}
\hline \multirow{2}{*}{ Variables } & \multirow{2}{*}{ Coefficient } & \multicolumn{5}{|c|}{ Marginal Effects } \\
\hline & & $\mathbf{P}\left(y_{i}=\mathbf{1} \mid \mathbf{X}_{i}\right)$ & $\mathbf{P}\left(y_{i}=2 \mid \mathbf{X}_{i}\right)$ & $\mathbf{P}\left(y_{i}=\mathbf{3} \mid \mathbf{X}_{i}\right)$ & $\mathbf{P}\left(y_{i}=\mathbf{4} \mid \mathbf{X}_{i}\right)$ & $\mathbf{P}\left(y_{i}=\mathbf{5} \mid \mathbf{X}_{i}\right)$ \\
\hline Age & $\begin{array}{c}-0.2292 * * * \\
(0.000)\end{array}$ & $0.0028^{*}$ & $0.0143^{* * *}$ & $-0.0078 * * *$ & $-0.0027 *$ & -0.0003 \\
\hline Educational level & $\begin{array}{l}-0.0607 \\
(0.301)\end{array}$ & 0.0007 & 0.0038 & -0.0021 & -0.0007 & -0.0001 \\
\hline Income level & $\begin{array}{l}0.0079 \\
(0.872)\end{array}$ & -0.0001 & -0.0005 & 0.0003 & 0.0001 & 0.000 \\
\hline $\begin{array}{c}\text { Financial } \\
\text { knowledge and } \\
\text { management }\end{array}$ & $\begin{array}{c}0.7211^{* * *} \\
(0.000)\end{array}$ & $-0.0088^{*}$ & $-0.0449 * * *$ & $0.0247 * * *$ & $0.0086^{*}$ & 0.0010 \\
\hline Future expectation & $\begin{array}{c}0.4081 * * * \\
(0.002)\end{array}$ & -0.0049 & $-0.0254 * * *$ & $0.0139 * *$ & 0.0049 & 0.0006 \\
\hline Social influence & $\begin{array}{c}-0.3377 * * * \\
(0.000)\end{array}$ & $0.0041^{*}$ & $0.0211 * * *$ & $-0.0115^{* * *}$ & -0.0040 & -0.0005 \\
\hline Wald Chi-squared & \multicolumn{6}{|c|}{167.01} \\
\hline$p$-value & \multicolumn{6}{|c|}{$0.0000 * * *$} \\
\hline Log likelihood & \multicolumn{6}{|c|}{-1203.2777} \\
\hline
\end{tabular}

Note: $* * *$ and $* * *$ shows that the coefficients are statistically significant at $0.01,0.05$ and 0.1 level of significance. Value given in parentheses are the p-value of the coefficient. 


\section{Conclusions}

This study aims at two objectives which were to investigate the retirement savings decision at different age groups, and to examine the relationship between several factors that provide an impact on retirement savings decision in Malaysia. The results revealed that there was significant difference in savings decisions towards retirement, and this finding was supported by the significant result in the ordered probit model. Although age was considered a determinant in affecting the decision towards retirement planning, financial knowledge and management, future expectation and social influences also provided important impact on this retirement decision. Most of the respondents agreed that they need the financial knowledge to manage their savings for retirement, as well as to belief that the life after retirement would be much more comfortable if they have enough savings. The influence of the surroundings contributed by family and friends was also one of the factors on the decisions to save. People tend to believe of what others are saying, and nowadays with the advancement of technology and social media, it is possible that the influence to save and plan for retirement could be increased by using this platform.

In a nutshell, this model could be used to determine the factors that affect retirement savings decisions and could benefit all Malaysians. The awareness to save for future life, especially after retirement, could be enhanced by introducing the financial literacy during secondary education in Malaysia, as well as holding numerous campaigns and advertisements to nurture this awareness. As a result, it is hoped that this resolution will make changes in the retirement issues in Malaysia.

\section{Acknowledgements}

The authors are acknowledging the financial support from grants of (PPPI/FST/0217/051000/11118) and (USIM/FRGS/FST/KPT/52420) from Universiti Sains Islam Malaysia.

\section{REFERENCES}

[1] A. A. Hadi. Retirement blues we can ill afford. News Straits Times. Online available from https://www.nst.com.my/opin ion/columnists/2019/08/517425/retirement-blues-we-can-ill -afford.

[2] N. F. M. Talib, H. A. Manaf. Attitude towards retirement planning behaviour among employees, Journal of Business and Management, Vol.1, No.1, 15-21, 2017.

[3] D. Ibrahim, Z. Mohamed Isa, N. Ali. Malaysian Savings Behavior towards Retirement Planning, International Conference on Economics Marketing and Management, Singapore, Vol. 28, 2012.

[4] N. S. M. Shariff, N. A. M. Isah. An empirical study on the determinants of retirement savings attitude in Malaysia, Journal of Physics: Conference Series, 1366 012110, 2019.

[5] M. K. Moorthy, T. D. Chelliah, C. S. Sien, L. C. Leong, N. Z. Kai, W. C. Rhu, W. Y. Teng. A study on the retirement planning behaviour of working individual in Malaysia, International Journal of Academic Research in Economics and Management Science, Vol.1, No. 2, 54-72, 2012.

[6] N. S. Mahdzan, S. Tabiani. The impact of financial literacy on individual saving: an exploratory study in the Malaysian, Transformations in Business \& Economics, Vol.12, No.1, 41-55, 2013.

[7] M. F. Mansor, C. C. Hong, N. H. Abu, M. S. Shaari. Demographic factors associated with retirement planning: a study of employees in Malaysian health sectors. Asian Social Science, Vol.11, No.13, 108-116, 2015.

[8] J. Binswanger, K. G. Carman. How real people make long-term decisions: The case of retirement preparation, Journal of Economic Behavior \& Organization. Vol. 81, No. 1, 39-60, 2012.

[9] A. Lusardi, O. S. Mitchell. Financial literacy and planning: implications for retirement wellbeing, Working paper, Wharton School, University of Pennsylvania, 2005.

[10] J. M. Jacob-Lawson, D. M. Hershey. Influence of future time perspective, financial knowledge and financial risk tolerance on retirement saving behaviors, Financial Services Review 14, 331-344, 2012.

[11] T. E. Garman, R. E. Forgue. Personal Finance, 8th edition, Boston: Houghton Mifflin Company, 2006.

[12] M. S. N. Pam. Social Influence. Online available form https://psychologydictionary.org/social-influence/

[13] W. M. Z. Wan Abdullah, W. N. R. A. Zainudin, W. W. Mohamad Ishak. The scale validation of public participation of renewable energy (RE) development in Malaysia: an exploratory factor analysis (EFA), International Journal of Recent Technology and Engineering (IJRTE), Vol.7, No. 4S2, 2018.

[14] J. F. Hair, W. C. Black, B. J. Babin, R. E. Anderson. Multivariate Data Analysis, 7th edition, Prentice Hall, 2010.

[15] D. W. Hosmer, S. Lemeshow. Applied Logistic Regression, 2nd edition, John Wiley \& Son, Inc., 305 -306. 2000.

[16] W. N. R. A. Zainudin, W. W. M. Ishak. Measuring public acceptance on renewable energy (RE) development in Malaysia using ordered probit model. In Journal of Physics: Conference Series, Vol. 890, No. 1, 012137, IOP Publishing. 2017. 